be found even on the most profusely infested trees and plants, and fruit growers and gardeners are hoping that the scourge has run its course for the present.

[This concludes the list of papers read by title.]

\title{
NOTES ON INSECTS AFFECTING THE COCOANUT TREES IN THE SOCIETY ISLANDS
}

By R. W. Doane, Stanford University, Cal.

In a previous issue of this JournaL, 1: 341, I have given a few notes on Aspidiotuis destructor and its work on the eocoanut trees in these islands. While this insect is responsible for the greatest injury to the trees, there are several others that are of more or less importance. Among the scale insects Hemichionaspis aspidistrae ranks next to $A$. destructor in numbers and probably in amount of damage done. The two are usually found together on the leaves and fruits. $H$. aspidistrae occurs on all parts (except the trunk and roots) of both the old and young trees, the white scales of the males often forming white patches that nearly or quite cover the leaflets on many of the leaves. But it is on the nuts that it is most abundant and most conspicuous. The husk of both the young and the old nuts are often almost completely covered with it. On account of this habit of attacking the husks of the nuts it is not as injurious as it would be if it confined its attention to the young tender leaves. I also collected it and had it sent to me from several of the islands of the group on a number of unidentified weeds and shrubs. Everywhere it is abundantly parasitized by a small chalcid, but I did not succeed in rearing the parasite. Lepidosaphes gloveri is often very abundant on the bases of the older leaves, but as long as its attacks are restricted to this part of the tree the damage done is not very great. It is everywhere badly parasitized. On some leaves practically all of the scales showed the small round hole where the parasite had escaped. On the young tender unfolding leaves of many of the trees, both old and young, are to be found large colonies of Pseudococcus pandani. Some of the young trees are seriously injured in this way, for as fast as the tender leaves break from their sheath the insects attack them and when abundant produce a considerable amount of honey dew. This mixed with the white floceulent excretion collects in large drops and masses in the folds of the leaves around and below the colony. No 
natural enemies of these insects were observed, but the fact that they are only to be found on protected parts of the tree would indicate that some predaceous form keeps them from spreading to more exposed parts. It is possible that the small skinks and geckos that are so abundant on many of the trees snap up any of the insects that are accessible. What seems to be the same species of mealy-bug occurs abundantly on the Pandanus. These are often in somewhat more exposed places and I have seen the larvæ of lacewing flies feeding on them. It is very likely that these larvæ attack the mealy-bug on the coacoanut trees as well. This is probably the same species of Pseudococcus that is reported as doing considerable damage to cocoanut trees in other groups of the South Sea Islands.

Toward the base of many of the older leaves on some of the trees may be seen small holes, from which flows a resin-like exudation. Often this has issued to such an extent that the whole lower portion of the leaf is covered, or it collects in lumps on the leaf below. Often bits of leaf-fiber and larval castings are mixed with the exudation. Around these holes the tissue of the leaf is more or less blackened and decayed. Two different types of these holes may be found, usually on the same tree, distinguishable principally by their size and the amount and extent of the injury. Both are made by the larve of weevils; a large one, the adult of which is about $13 \mathrm{~mm}$. in length, and a smaller one about one half the size, kindly identified by $\mathrm{Mr}$. Schwarz, through Doctor Howard, as Sphenophorus obscurus Boisd. and Calandra taitensis Guérin. The larger larva usually works çloser to the base of the leaf, often killing the leaf by burrowing all through it. Sometimes the larva will keep close to the edge of the leaf or go only as far in as the center, boring a tortuous chamber from $1 / 2$ to $3 / 4$ an inch in diameter. The burrow is usually filled with the chaff and castings and the larva is usually found at the upper end of the burrow. Often from the blackened portion of the infested leaf the resinous exudation will be issuing in several places, making it appear that several larve are at work in the same leaf. This is sometimes the case, but a single larva may bore along a leaf stem for 12 to 15 inches, causing the exudation to flow in abundance from several openings and making many large discolored spots, beneath which the tissue is soft and decayed. The older leaves are usually attacked. After attaining its full growth the larva bores close to the surface and constructs a rude oval cocoon out of the fiber that it has been eating and transforms to the pupa stage, from which it later issues as the adult beetle. These cocoons may usually be found quite abundantly in the chaff at the base of old leaves or in the old leaves. In some in- 
stances the larva bores into the trunk of the tree for a short distance where the broad leaf-base joins the tree. In one instance I found the beetle quite abundant in and around the growing tip of a young tree that was dying, whether as a result of the work of the beetle or from some other cause I was unable to determine.

The smaller weevil, $C$. taitensis, seems to be much more abundant and on account of its habits is perhaps more injurious than the larger species. It is found most commonly boring into the edge of the base of the leaf-stem. Its presence is indicated, as with the larger species, by the presence of a gummy exudation mixed with castings. These are often in the shape of long twisted strings, $1 / 4$ to $1 / 2$ inch long. As the larvæ do not work as deep in the tissue of the leaf as do those of the larger species, the damage here is not very great, but when they work further out at the base of the leaflets many of the leaflets are destroyed.

A still more serious damage is done where the larve attads the spikelets, killing them at the point of attack and working toward the base. As long as they confine their work to the portion of the spike having only the male flowers the damage is not serious, because the number of these flowers is so great. But when they attack the spikelet below the female or fruiting flower, the young fruit is killed. After the larva has become full grown it makes for itself a rather long cell, with a very thin wall on one side, and, without making a cocoon, changes to the pupa, from which, later, the adult emerges and breaks through the thin wall of its cell.

Another insect that is doing much damage to many of the cocoanut trees on all parts of these islands is the larva of a small moth that works on the underside of the leaflets, eating away the lower surface and causing the whole leaflet to turn brown and die. Often a large portion of the leaf is thus destroyed, giving the whole tree a very ragged appearance and of course doing considerable damage when many leaves are affected. The larva spins a thin, protective net of silk as it feeds. Along the midrib or at the base of the leaflet a denser web is formed, to which the larva, by a peculiar jerky motion, retreats when disturbed. A very few pupæe were taken, but I was not able to rear the adult moth, so I cannot identify the species.

There is another small moth larva that may prove to be of considerable importance on account of its habit of attacking the male flower buds as soon as they are exposed by the opening of the spathe. Many of the spikelets are nearly or quite stripped of their buds before the flower opens. The larva works just at the base of the bud, usually inside, often extending its work out along the stem for a short dis- 
tance, and sometimes boring into the spikelet. In some instances the web may connect two or three near-by buds, the larva resting between or in one of them. The larvæ when disturbed or driven from their retreat move along the spikelet with a quick, jerky motion. No adults were reared, so I do not know the species.

On some of the trees, where male spikelets were in bloom, the spike would be literally covered with two species of Oedemerids, Ananca livida Fab. (Oliv.), and A. collaris Sharp (also identified by $\mathrm{Mr}$. Schwarz), the former being more abundant. They were feeding on the pollen and where a spike was badly attacked practically all the pollen was destroyed. This might prove to be of some importance if many trees were attacked. Mr. Schwarz points out that the members of the closely related American genus Oxacis breed in rotten wood and that the imagoes of some of the Florida species congregate on the flowers of palm trees. A thorough study of the insect enemies of the cocoanut trees in this region would doubtless result in a considerable saving to the planters.

\section{RECENT WORK IN INSECT BEHAVIOR AND ITS ECONOMIC SIGNIFICANCE ${ }^{1}$}

By Willuak B. Herms, Assistant Professor in Entomology, University of California

Animal behavior has been the subject of much investigation during the past ten years, with the purpose of analyzing the organism's method of orientation to a stimulus and the method of locomction toward or away from such a source of stimulation. Paper after paper: has been published, affording considerable information on the subject,- the "tropism" scheme, the "trial and error" method, and the "random movement" method have been advanced and criticised, internal factors and external factors have been considered, sundry methods of experimentation have been applied,-but little has been done with an economic aim. Certainly a narrow viewpoint would be evident were we to expect an immediate economic return for every new effort in science; it must be considered that many if not all applied sciences have found their origin in pure science, and a heedless attitude toward the same may result in actual hindrance to progress. But the agriculturist who has to deal at first hand with the pests of the orchards and of the field may well ask the question of the student of animal

${ }^{1} \mathrm{~A}$ paper presented at the Watsonville (California) Entomological Conference, Aug. 25, 1908. 